ECCOMAS

Proceedia
COMPDYN 2021

$8^{\text {th }}$ ECCOMAS Thematic Conference on Computational Methods in Structural Dynamics and Earthquake Engineering

M. Papadrakakis, M. Fragiadakis (eds.)

\title{
INFLUENCE OF THE DYNAMIC SOIL-STRUCTURE INTERACTION IN CONCRETE FRAMES WITH INCORPORATED VISCOUS DAMPERS
}

\author{
Andrés M. Cortés ${ }^{1}$, Francisco J. Peña ${ }^{2}$, Orlando Cundumí ${ }^{1}$ \\ ${ }^{1}$ Pontificia Universidad Javeriana, Cali, Colombia \\ Calle18\#118-250 Avenida Cañasgordas, Cali-Colombia \\ e-mail: \{andrescortes97, orlando.cundumi\}@javerianacali.edu.co \\ ${ }^{2}$ Wiss, Janney, Elstner Associates, Inc. Indianapolis, USA \\ 8606 Allisonville Road Suite 205 Indianapolis \\ email: fpena@wje.com
}

\begin{abstract}
Essential facilities, such as hospitals, communication systems, highways, bridges, among others, play a significant role in a community. These facilities are vital, especially after being hit by a natural hazard. They must remain functional after a significant event to provide essential services to the community. The implementation of control systems during the structural design and rehabilitation stages enables an attractive manner for this type of structure to dissipate the dynamic response under major disturbance events. Typically, the design stage of structural control systems focuses its attention on the asset's structural configuration. Under seismic events, the structure's response can be altered by the interaction between the structure and the soil underneath. In this paper, the dynamic response's influence is evaluated through numerical simulation by including the effects of soil-structure interaction in a concrete moment resistant frame with viscous fluid-type energy dissipation systems. For this analysis, seven ground motion records were selected for the analysis, considering their frequency and source of content. These records are matched to the corresponding building code design response spectrum for areas prone to high seismicity. Similarly, the soil profiles used for the analysis correlates with the same seismic hazard zone. The analyzed structure corresponds to an essential facility of high importance modeled as a two-dimensional concrete moment resistant frame. The analysis is performed on a seven-story building implementing viscous dampers. Two cases are studied: implementing and neglecting the effects of the soil-structure interaction. The results for the case-study show a significant increase in the dynamic response in terms of displacement, interstory drift, and base shear when considering soil-structure interaction.
\end{abstract}

Keywords: Energy Dissipation System, Nonlinear Analysis, Soil-Structure Interaction. 


\section{INTRODUCTION}

For assets for the built environment, structural damage may occur due to medium to highintensity seismic events. These effects can damage structural and non-structural elements, and on some unfortunate occasions, they have resulted in casualties. During the last decades, multiple researchers have focused their attention on alternatives for controlling the structure's response due to seismic loads in order to guarantee people' safety and to minimize the amount of inflicted damage into the buildings [1]. The seismic design aims to develop structural configurations to resist earthquake loads, providing reliability, durability, and, most importantly, minimizing casualties. Traditionally, the dissipation of energy has been considered by the deformation and damage of the building components. In the last decades, different methodologies have been developed for the design of structures (e.g., buildings, bridges, dams) with the objective of dissipating the energy while preserving the investment. For instance, displacement-based design and accounting for enough ductility into the structure are used alternatives for energy dissipation. The latter represents the basis of the current building design codes. Alternatively, there are other methods, such as the incorporation of energy dissipation systems, including base isolation, known as control systems. These systems are typically implemented on essential facilities to control the seismic response and remain functional during and after an earthquake [2-7]. Recently, it became evident that the traditional design of structures does not represent a sufficient solution to prevent the collapse of certain structures [8]. Rather, it is necessary to implement solutions that enable immediate occupancy while minimizing required repairs and functionality interruptions after medium to high-intensity earthquakes [8]. This can be achieved by incorporating control systems to reduce structure forces and displacements among seismic events. Incorporating control systems as an alternative for the design of new structures and the rehabilitation of existing structures is becoming more popular among building codes. Some examples of this implementation include the Colombian current code NSR-10 and the new one that is being developed AIS 700 (Asociación Colombiana de Ingeniería Sísmica), ASCE 7-16 (American Society of Civil Engineers), the Eurocode, and the Chilean Standard NCh. Additionally, previous studies have shown that the implementation of control systems may enable a life-time reduction of the structure's cost, in comparison with the cost associated with structures designed in a traditional manner, due to the capability to reach inelastic deformations during earthquakes, suffering minimal damage, providing postearthquake operability, and reducing the need for repair [8]. Control systems have been implemented in multiple buildings around the world to reduce the dynamic behavior of the structure, for example: St. Francis Towers (Mandaluyong, Philippines), Churchill Hotel (San Diego, California, USA), King County Courthouse (Seattle, Washington, USA), Opera House (San Francisco, California, USA) and 3 Com (Foster City, California, USA) [9, 10].

However, these structures are typically designed neglecting any soil-structure interaction [11]. In structural dynamics, a structure's behavior is analyzed considering a set of discrete elements, modeled following a set of equations of motion to estimate displacements and stresses. For the case of soil dynamic analysis, the study is performed similarly while taking into account the effect of the soil, and therefore the resulting structure's displacements and stresses differ [12]. This effect is known as "Dynamic Soil-Structure Interaction" (DSSI). According to Kausel [13], the DSSI concept is hard to define completely. Still, in general terms, it refers to static and dynamic phenomena that occur between the ground and a much more rigid structure. For example, the seismic wave amplification in the ground and the dynamic interactions between different soil layers are factors to consider during a DSSI analysis. Other studies showed that DSSI consideration could significantly influence the dynamic response of structures [12-18]. This influence is mainly seen in three aspects: i) the change in the dynamic 
characteristics of the soil-structure system such as frequencies and modes of vibration; ii) the increasing in damping within the system due to the transference of the structure's energy into the ground; and iii) the soil moving properties influence the analysis [11]. Recent studies have shown that the effects of the DSSI have a greater influence on the structural response in terms of base shear, performance level, and inter-story drifts when is supported on soft soils [17].

To evaluate the influence that the DSSI has on the response of concrete frames with viscous damper devices, we analyzed a seven-story concrete frame with and without implemented control systems. First, seven representative seismic records were selected, considering representative characteristics such as their frequency content. These records were matched to the corresponding response spectrum of a high seismic hazard zone, defined by the design codes. Subsequently, the matched records were filtered through a soil profile to obtain surface records. With the same profile data, the foundation stiffness was calculated at the surface level to perform a more accurate analysis of the structure and the soil at the transition zone between both systems. The soil stiffness and the earthquakes acting at the surface were considered during the analysis. For the seismic response analysis, the analytical model of the structure was done in the finite element software ETABS [21]. The analysis was performed for four cases: fixed and flexible base with and without viscous dampers. The results are presented in terms of the maximum inter-story drift, the base shear, and hysteretic curves for the viscous dampers. Although the complete analysis includes more models of structures with different characteristics (e.g., different number of bays, stories, dimensions) [22], only one structural model with seven stories and five bays are presented within this paper.

\section{GROUND MOTIONS}

\subsection{Ground motion selection}

For the dynamic analysis in the time domain, ground motion records must meet certain criteria $[21,22]$ : must be a minimum of three different acceleration records or the average value of seven acceleration records, all of them different and representative of the expected ground motions at that zone; they must be events with magnitude, distance to the seismic source and rupture mechanisms similar to the ones for the location of the case-study; and covering the broadest possible range of frequencies.

Following the guidelines outlined above, the seismic acceleration records were selected from the Pacific Earthquake Research Center (PEER), for the NGA-West2 database [25]. Ranges of magnitude and distance to the seismic source were established, according to the analysis of the disaggregation of the seismic threat of the seismic micro zoning project for the city of Cali, Colombia [26]. Two different searches were performed for the analysis: i) magnitude between 5.5 and 6.7 and a distance between 0 and 40 kilometers; ii) magnitude between 7.0 and $8.5 \mathrm{y}$ distance between 110 and 180 kilometers. Also, an average shear wave velocity range of at least $500 \mathrm{~m} / \mathrm{s}$ was required [27].

Table 1 shows the seven selected ground motion records and a summary of some of their most representative characteristics.

\begin{tabular}{ccccccc}
\hline Event & Station & Year & $\begin{array}{c}\text { Magnitude } \\
\text { Mw }\end{array}$ & $\begin{array}{c}\text { Distance to } \\
\text { rupture sur- } \\
\text { face }(\mathrm{km})\end{array}$ & $\begin{array}{c}\text { Failure } \\
\text { Mechanism }\end{array}$ & $\begin{array}{c}\text { Vs30 } \\
(\mathrm{m} / \mathrm{s})\end{array}$ \\
\hline ChiChi, Taiwan & TAP046 & 1999 & 7.62 & 118.34 & $\begin{array}{c}\text { Reverse } \\
\text { Oblique }\end{array}$ & 816.9 \\
Kocaeli, Turkey & Eregli & 1999 & 7.51 & 142.29 & Strike Slip & 585.09
\end{tabular}




\begin{tabular}{ccccccc}
\hline & & & & & \\
Niigata & NIG023 & 2004 & 6.63 & 25.82 & Reverse & 654.76 \\
Northridge-01 & LA-Chalon Rd & 1994 & 6.69 & 20.45 & Reverse & 740.05 \\
Northridge-01 & LA Dam & 1994 & 6.69 & 5.92 & Reverse & 628.99 \\
Northridge-01 & $\begin{array}{c}\text { Santa Susana } \\
\text { Ground }\end{array}$ & 1994 & 6.69 & 16.74 & Reverse & 715.12 \\
San Fernando & $\begin{array}{c}\text { Lake Hughes } \\
\# 12\end{array}$ & 1971 & 6.61 & 19.3 & Reverse & 602.1 \\
\hline
\end{tabular}

Table 1: Selected ground motions.

\subsection{Target response spectrum}

The design elastic response spectrum was defined according to the Colombian NSR-10, whose parameters are shown in Table 2, taking into account an importance coefficient (I) of 1.25. From this spectrum, the structure is designed without viscous dampers. For the structure with incorporated viscous dampers, a response spectrum of the maximum considered earthquake must be used. According to ASCE 7-16 [24], the response spectrum for the controlled structure must be determined using the code target spectrum amplified by 1.5. Figure 1 shows the two target spectrums.

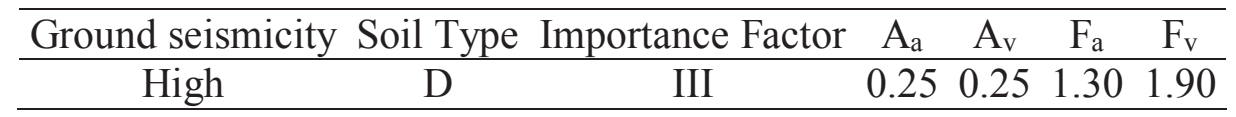

Table 2: Parameters for the construction of the design spectrum according to Colombian design code NSR-10 $[23]$.

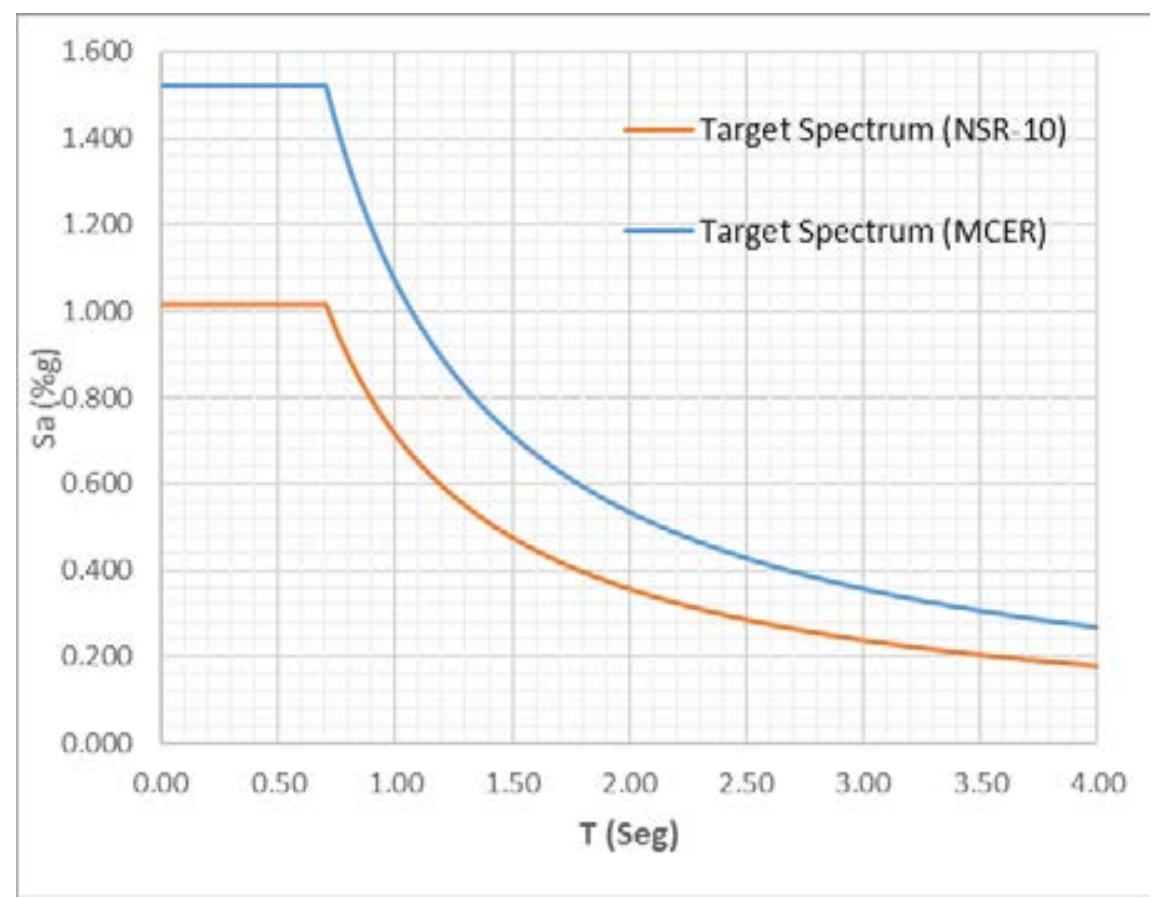

Figure 1: Target response spectrums.

\subsection{Spectral matching}

Considering that the acceleration records were selected from a location different than the one from the case-study, it is necessary to match these records according with the target spectrum. This matching process guarantees compatibility in terms of the frequency content and 
tectonic regimebetween the acceleration records and the case-study location. Using the time domain matching methodology described in $[28,29]$, it is possible to modify the existing acceleration records while preserving the non-stationary character of the reference ground motion records. The methodology implements a tapered cosine wavelet for adjusting the acceleration records, resulting in records without drift in the corresponding displacements and velocities. This adjustment procedure ensures stability, efficiency, and speed in obtaining the numerical solution of the spectral match [29].

The acceleration records are matched to the target response spectrum employing the wavelet algorithm from SeismoMatch, a software by SeismoSoft [30]. Figure 2 shows the comparison between the originalacceleration record for the 1971 San Fernando earthquake (recorded at the rock level), and the matched records with respect to the NSR-10 response spectrum and the maximum considered earthquake spectral response $\left(\mathrm{MCE}_{\mathrm{R}}\right)$.

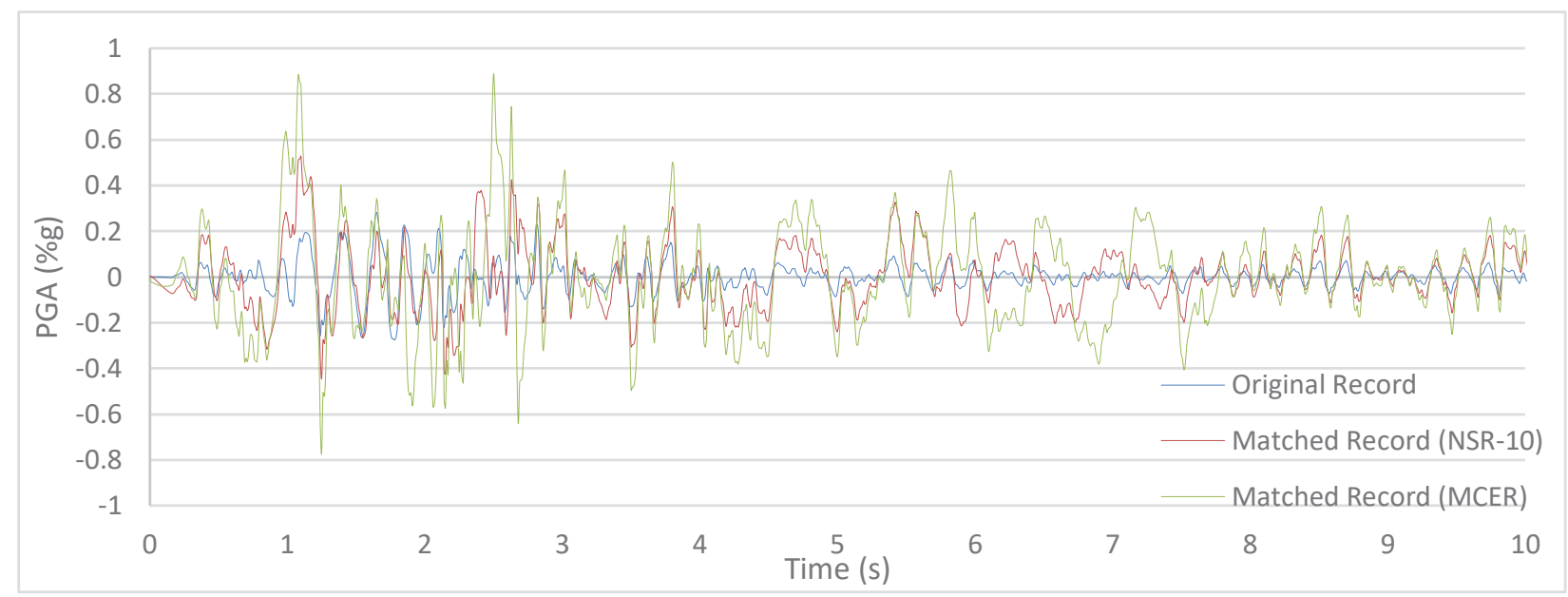

Figure 2: Comparison of original and matched accelerogram records to the Colombian code NSR-10 and MCER target spectrum for 1971 San Fernando Earthquake.

Figure 3 shows the comparison of the mean matched spectrums to its respective target spectrum of the Colombian code NSR-10 (For the model without viscous dampers) and the $\mathrm{MCE}_{\mathrm{R}}$ (For the model with viscous dampers).

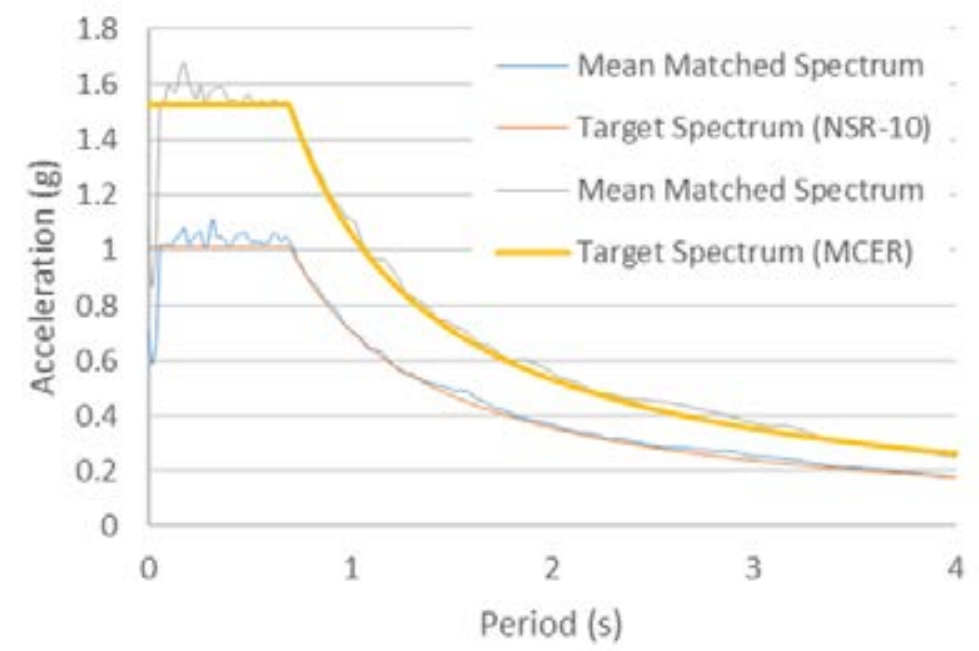

Figure 3: Comparison of the Colombian NSR-10 and MCER target spectrum and their respective mean response spectrum for the original seismic records. 


\subsection{Non-linear properties of the soil}

Generally, for stiff structural systems, foundation deformations can represent a significant component of system flexibility and ignoring it can result in bad characterization of properties as fundamental mode frequency and damping ratio [31]. Foundation damping results from the relative movements of the foundation and the supporting soil and these cause displacement and rotations of the structure relative to the free field. The difference between the foundation input motion and free-field motion gives rise to energy dissipation by radiation damping and hysteretic soil damping, and this affects the overall system damping [32].

Site effects are caused by the amplification of the seismic waves as they travel from the rock to the surface. This amplification is the result of the seismic wave traveling through the different layers from the soil profile. The most common physical properties used to characterize these soil layers include their thickness $(\mathrm{H})$, the shear wave velocity $(\mathrm{Vs})$, the specific weight $(\gamma)$, the friction angle of the material $(\Phi)$, the modulus of elasticity $(E)$, and the shear modulus $(G)$ of the soil. Table 3 shows a summary of the soil layers implemented within this study and their representative characteristics.

\begin{tabular}{ccccccc}
\hline Soil Layer & $\mathrm{H}[\mathrm{m}]$ & $\mathrm{Vs}[\mathrm{m} / \mathrm{s}]$ & $\begin{array}{c}\gamma \\
{\left[\mathrm{kN} / \mathrm{m}^{3}\right]}\end{array}$ & $\begin{array}{c}\Phi \\
{\left[{ }^{\circ}\right]}\end{array}$ & $\begin{array}{c}\mathrm{E} \\
{[\mathrm{MPa}]}\end{array}$ & $\begin{array}{c}\mathrm{G} \\
{[\mathrm{MPa}]}\end{array}$ \\
\hline Surface Clay & 4 & 157 & 18.5 & 25 & 123.11 & 46.28 \\
Clay with lens & 11 & 244 & 18.5 & 32 & 297.35 & 111.79 \\
Hard Clay & 7 & 570 & 20.0 & 33 & 1754.27 & 659.50 \\
Peat Clay & 8 & 736 & 21.8 & 42 & 3188.07 & 1198.52 \\
\hline
\end{tabular}

Table 3: Soil profile data.

The implementation of the soil layers effects can be carried out using ProShake 2.0 [33], a software that finds the solution of ground response problem in the frequency domain, whose input acceleration records are represented as a sum of series of sine waves of different amplitudes, frequencies, and phase angles. Filtering the acceleration records using the transfer functions from the different soil layers, the response of the soil profile for each of the waves is obtained. Figure 4 and Figure 5 shows the rock records for the San Fernando earthquake and their comparison with the same record filtered through the soil profile.

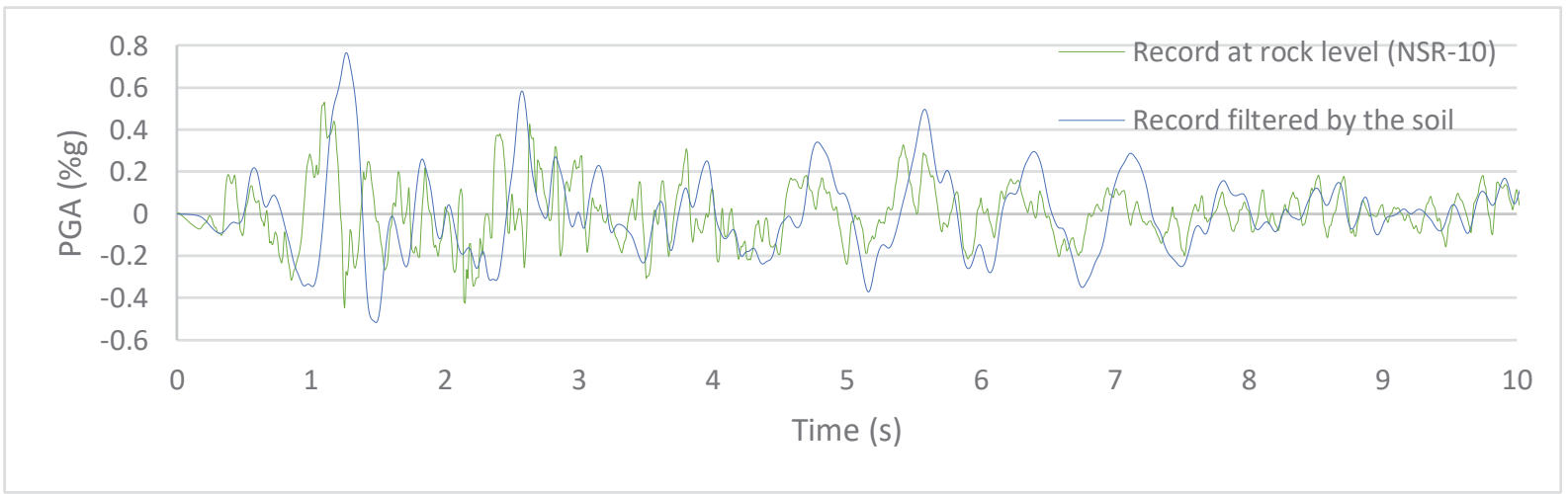

Figure 4: Comparison of matched records to Colombian NSR-10 and the same records filtered through the soil profile for 1971 San Fernando earthquake. 


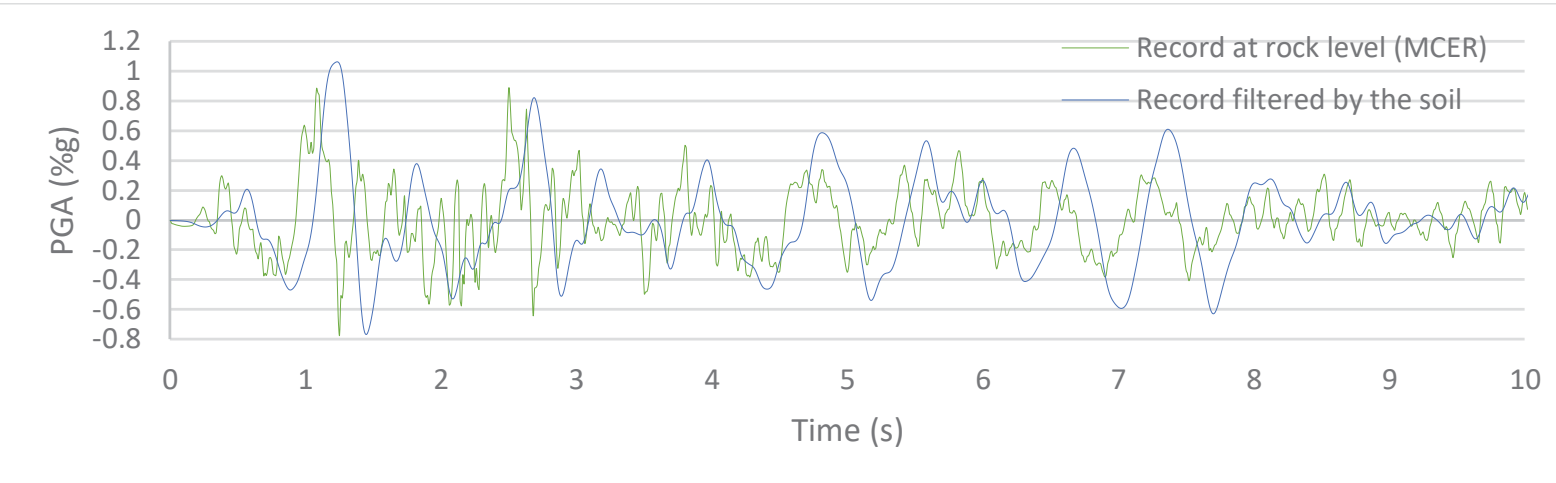

Figure 5: Comparison of matched records to $\mathrm{MCE}_{\mathrm{R}}$ spectrum and the same records filtered through the soil profile for 1971 San Fernando earthquake.

\subsection{Soil structure interaction}

Using the soil profile data shown in Table 3, the stiffnesses of the foundation are calculated at the surface level to posteriorly included in the flexible base model. This calculation is carried out using the following equations from [34]:

$$
\begin{aligned}
K_{x, \text { sur }} & =\frac{G B}{2-v}\left[3.4\left(\frac{L}{B}\right)^{0.65}+1.2\right] \\
K_{z, \text { sur }} & =\frac{G B}{1-v}\left[1.55\left(\frac{L}{B}\right)^{0.75}+0.8\right] \\
K_{y y, \text { sur }} & =\frac{G B^{3}}{2-v}\left[0.47\left(\frac{L}{B}\right)^{2.4}+0.034\right]
\end{aligned}
$$

where, $K_{x, \text { sur }}, K_{z, \text { sur, and }} K_{y y, \text { sur }}$ are the stiffnesses for the translation along the $\mathrm{X}$-axis, $\mathrm{Z}$ axis, and the rocking effect about the $\mathrm{Y}$-axis, respectively, $\mathrm{G}$ is the shear modulus, $v$ is the Poisson ratio, $\mathrm{B}$ is the rectangular foundation width, and $\mathrm{L}$ is the rectangular foundation length.

For the flexible base model a foundation beam 0.60 meters wide and discretized in segments of 1.0 meters long, is implemented. Using equations 1 through 3, the following stiffness values are obtained: $\mathrm{K}_{\mathrm{x}, \mathrm{sur}}=98752.0 \mathrm{kN} / \mathrm{m}, \mathrm{K}_{\mathrm{z}, \mathrm{sur}}=127388.3 \mathrm{kN} / \mathrm{m}$, and $\mathrm{K}_{\mathrm{yy}, \text { sur }}=$ $24402.8 \mathrm{kN}-\mathrm{m}$.

\section{NUMERICAL MODEL}

The seven-story frame is modeled in ETABS considering the geometry presented in Figure 6 for both cases with and without incorporating viscous dampers.
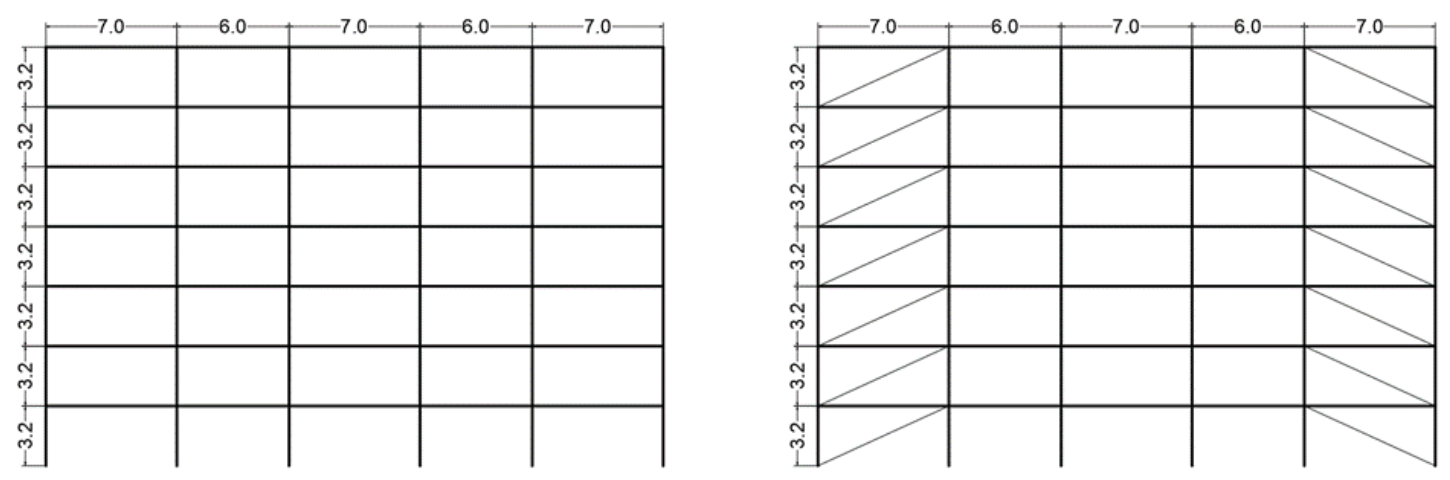
Figure 6: 7-story frame geometry for the case (a) without viscous dampers and (b) with viscous dampers. Dimensions in meters.

Structural elements are modeled using a value of concrete compressive strength of $28 \mathrm{MPa}$ and reinforcing steel with yield strength of $420 \mathrm{MPa}$. The structural design of the case-study building is performed in accordance with the NSR-10 and performing a dynamic modal spectral analysis to determine that the maximum inter-story drift is less than established limit of one percent. Additionally, an adequate capacity of structural elements needs to be guaranteed with respect to the expected load demands that the structure is expected to withhold.

According to ASCE 7-16, the base shear used for the design of the main system for the structure with viscous dampes must not be less than 75 percent of the originally determined base shear. Consequently, the reduction in the lateral forces for the system results in a reduction on the transversal section of the structural elements from the main system.

Viscous dampers were incorporated into the model using link elements with a non-linear exponential damper. The non-linear properties were introduced considering a moderate damage level in a moderate-height building [35] and following the methodology presented in [36]:

Firstly, the response reduction factor B was calculated using the following equation:

$$
B=\frac{D_{\max }}{D_{o b j}}
$$

where $\mathrm{D}_{\max }$ is the maximum drift obtained in the structural analysis and $\mathrm{D}_{\mathrm{obj}}$ is the target drift, which in this case is 0.0051 for a moderate damage level according to [35]. A structure's effective damping of 35 percent is set as the target, meaning that viscous dampers must contribute to $30 \%$ of total structural damping. Then, the damping coefficient $\mathrm{C}$ was calculated for each floor using the equation below:

$$
C=\zeta \frac{k_{i}}{\eta_{i}} * \frac{T}{\pi} * \frac{1}{\cos _{\theta_{j}}^{2}}
$$

where $\zeta$ is the damping ratio, $k_{i}$ is the stiffness for the $\mathrm{i}$-th story, $\eta_{i}$ is the number of viscous dampers per story, $\mathrm{T}$ is the fundamental period of the structure, and $\theta_{j}$ is the inclination angle for the viscous dampers.

The following non-linear properties for the viscous dampers were determined: damping coefficient $\mathrm{C}=2553.59 \mathrm{kN}-\mathrm{seg} / \mathrm{m}$, velocity exponent $\alpha=0.5$, brace stiffness $\mathrm{K}=202630.16$ $\mathrm{kN} / \mathrm{m}$, obtained by axial stiffness equation of a brace element using physical properties of a steel section HEB200. The maximum damper force can be obtained by using the equations shown on [36]:

$$
\begin{gathered}
F=C(V)^{\alpha} \\
V=\frac{2 \pi}{T} 0.02 x H_{\text {story }} x \operatorname{Cos}(\theta)
\end{gathered}
$$

where $\mathrm{F}$ is the damping force, $\mathrm{V}$ is the velocity, $\mathrm{T}$ is the fundamental period, $H_{\text {story }}$ is the height of the analyzed story, and $\theta$ is the damper inclination angle.

\subsection{Load considerations}

A load assessment was carried out and summarized in Table 4Table 5.

\begin{tabular}{lc}
\hline \multicolumn{2}{c}{ Dead Loads } \\
\hline Joist slab & $3.00 \mathrm{kN} / \mathrm{m}^{2}$
\end{tabular}


Floor finishes

Facade and partition walls

Mechanical, electrical and plumbing systems (MEP)

Ceiling finishes

SUM OF DEAD LOADS
$1.50 \mathrm{kN} / \mathrm{m}^{2}$

$3.00 \mathrm{kN} / \mathrm{m}^{2}$

$0.55 \mathrm{kN} / \mathrm{m}^{2}$

$0.25 \mathrm{kN} / \mathrm{m}^{2}$

$8.30 \mathrm{kN} / \mathrm{m}^{2}$

Table 4: Dead loads included in the analysis of the seven-story frame building.

\begin{tabular}{ll}
\hline \multicolumn{2}{c}{ Live Loads } \\
\hline Operating room & $4.00 \mathrm{kN} / \mathrm{m}^{2}$ \\
SUM OF LIVE LOADS & $4.00 \mathrm{kN} / \mathrm{m}^{2}$ \\
\hline
\end{tabular}

Table 5: Live loads included in the analysis of the seven-story frame building.

\section{RESULTS}

Table 6 shows the Peak Ground Acceleration (PGA) values of the original, matched and filtered acceleration records and it shows that PGA for the matched records to MCE $\mathrm{R}_{\mathrm{R}}$ have an increase of approximately 50\% comparing them to the matched records to the NSR-10.

Similarly, Table 7 shows the maximum Fourier amplitude for an analysis in the frequency domain. A graphic example of frequency content is shown for the San Fernando Earthquake on Figure 7. It is important to notice that the maximum Fourier amplitude has an average increase of $80 \%$ when the soil effects are considered.

\begin{tabular}{cccccc}
\hline \multirow{2}{*}{ Earthquake } & \multicolumn{5}{c}{ PGA } \\
\cline { 2 - 6 } & $\begin{array}{c}\text { Original Rec- } \\
\text { ord }\end{array}$ & \multicolumn{2}{c}{ Matched NSR-10 } & \multicolumn{2}{c}{ Matched MCE R $_{\mathbf{R}}$} \\
\cline { 2 - 6 } & 0.083 & 0.622 & Surface & Rock & Surface \\
\hline ChiChi & 0.087 & 0.404 & 0.671 & 0.953 & 0.912 \\
Kocaeli & 0.405 & 0.734 & 0.774 & 0.596 & 0.998 \\
Niigata & 0.183 & 0.562 & 0.678 & 0.806 & 1.019 \\
Northridge CHL & 0.324 & 0.569 & 0.897 & 0.864 & 0.926 \\
Northridge LDM & 0.231 & 0.533 & 0.717 & 0.755 & 1.181 \\
Northridge SSU & 0.282 & 0.527 & 0.764 & 0.887 & 0.860 \\
San Fernando & & &
\end{tabular}

Table 6: PGA comparison between the different evaluated cases.
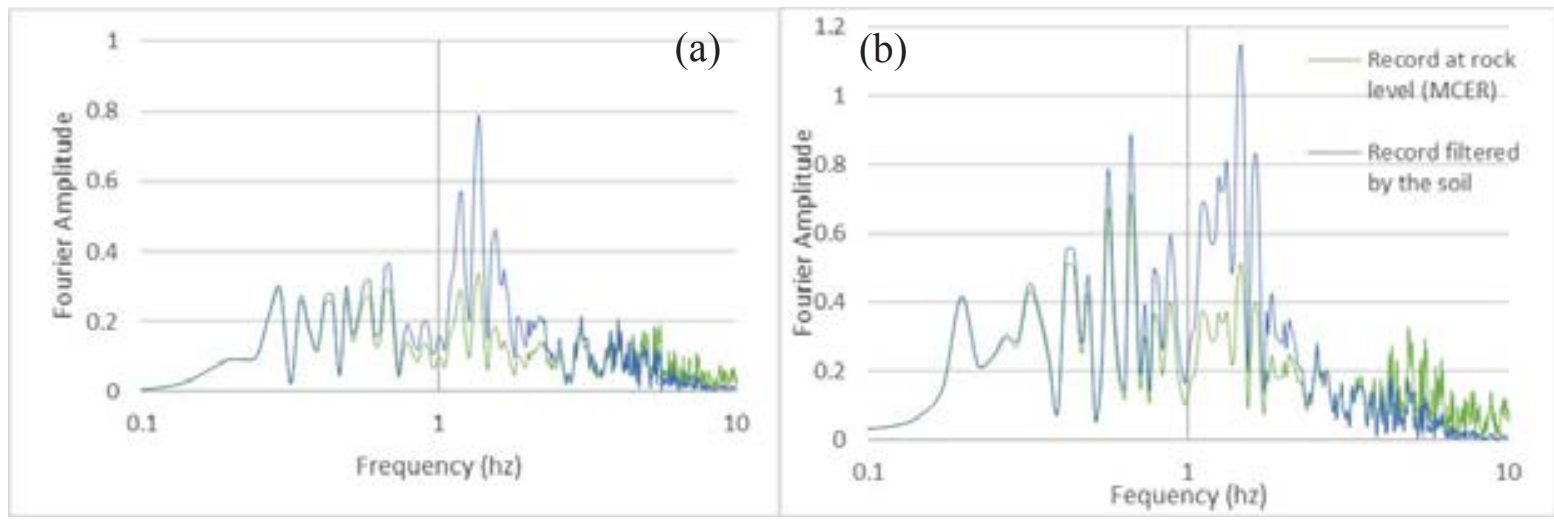

Figure 7: Frequencial content for matched record to the (a) Colombian Code NSR-and the same record filtered through the soil profile for San Fernando earthquake; (b) ASCE 7-16 Spectrum and the same record filtered through the soil profile for San Fernando earthquake. 


\begin{tabular}{cccccc}
\hline \multirow{2}{*}{ Event } & \multicolumn{5}{c}{ Maximum Fourier Amplitude } \\
\cline { 2 - 5 } & $\begin{array}{c}\text { Original } \\
\text { Record }\end{array}$ & \multicolumn{2}{c}{ Matched NSR-10 } & \multicolumn{2}{c}{ Matched MCE $_{\mathbf{R}}$} \\
\cline { 2 - 5 } & 0.063 & 0.445 & 1.081 & 0.738 & 1.508 \\
ChiChi & 0.102 & 0.613 & 1.192 & 0.873 & 1.390 \\
Kocaeli & 0.140 & 0.364 & 0.689 & 0.518 & 1.048 \\
Niigata & 0.202 & 0.396 & 0.785 & 0.692 & 1.194 \\
Northridge CHL & 0.243 & 0.379 & 0.716 & 0.527 & 0.875 \\
Northridge LDM & 0.142 & 0.419 & 1.080 & 0.537 & 1.067 \\
Northridge SSU & 0.142 & 0.338 & 0.786 & 0.705 & 1.148 \\
San Fernando & 0.144 & 0.379 & \\
\hline
\end{tabular}

Table 7: Maximum Fourier amplitude comparison between the different evaluated cases.

For the structural model, the fundamental period for each case is shown in Table 8. The increment in the fundamental period for the structures with the viscous dampers results from the reduced section in structural elements (i.e., reduced stiffness).

\begin{tabular}{lc}
\hline \multicolumn{1}{c}{ Case } & Fundamental period (s) \\
\hline Fixed base without viscous dampers & 0.354 \\
Flexible base without viscous dampers & 0.382 \\
Fixed base with viscous dampers & 0.450 \\
Flexible base with viscous dampers & 0.484 \\
\hline
\end{tabular}

Table 8: Fundamental periods for studied cases.

Table 9 show the maximum displacement and acceleration values for response of the structure's top floor, showing valuos for all seven earthquake records for the 7-story frame building with viscous damper incorporation for the fixed base case and flexible base case, respectively.

\begin{tabular}{ccccc}
\hline \multirow{2}{*}{ Event } & \multicolumn{3}{c}{ Maximum Displacement $(\mathbf{m m})$} & Maximum Acceleration $\left(\mathbf{m} / \mathbf{s}^{\mathbf{2}}\right)$ \\
\cline { 2 - 5 } & Fixed Base & $\begin{array}{c}\text { Flexible } \\
\text { Base }\end{array}$ & Fixed Base & Flexible Base \\
\cline { 2 - 5 } & 23.7 & 50.4 & 10.3 & 7.7 \\
ChiChi & 26.1 & 52.9 & 12.0 & 13.2 \\
Kocaeli & 38.1 & 62.2 & 14.3 & 11.9 \\
Niigata & 23.3 & 52.7 & 10.4 & 8.3 \\
Northridge CHL & 24.0 & 66.1 & 12.4 & 13.3 \\
Northridge LDM & 24.7 & 51.6 & 13.0 & 10.9 \\
Northridge SSU & 25.0 & 64.2 & 11.9 & 10.8 \\
San Fernando &
\end{tabular}

Table 9: Maximum displacement and acceleration values for the seven records.

The inter-story drift response is also shown in Figure 8 for the fixed base model and the flexible base model incorporating viscous dampers. 

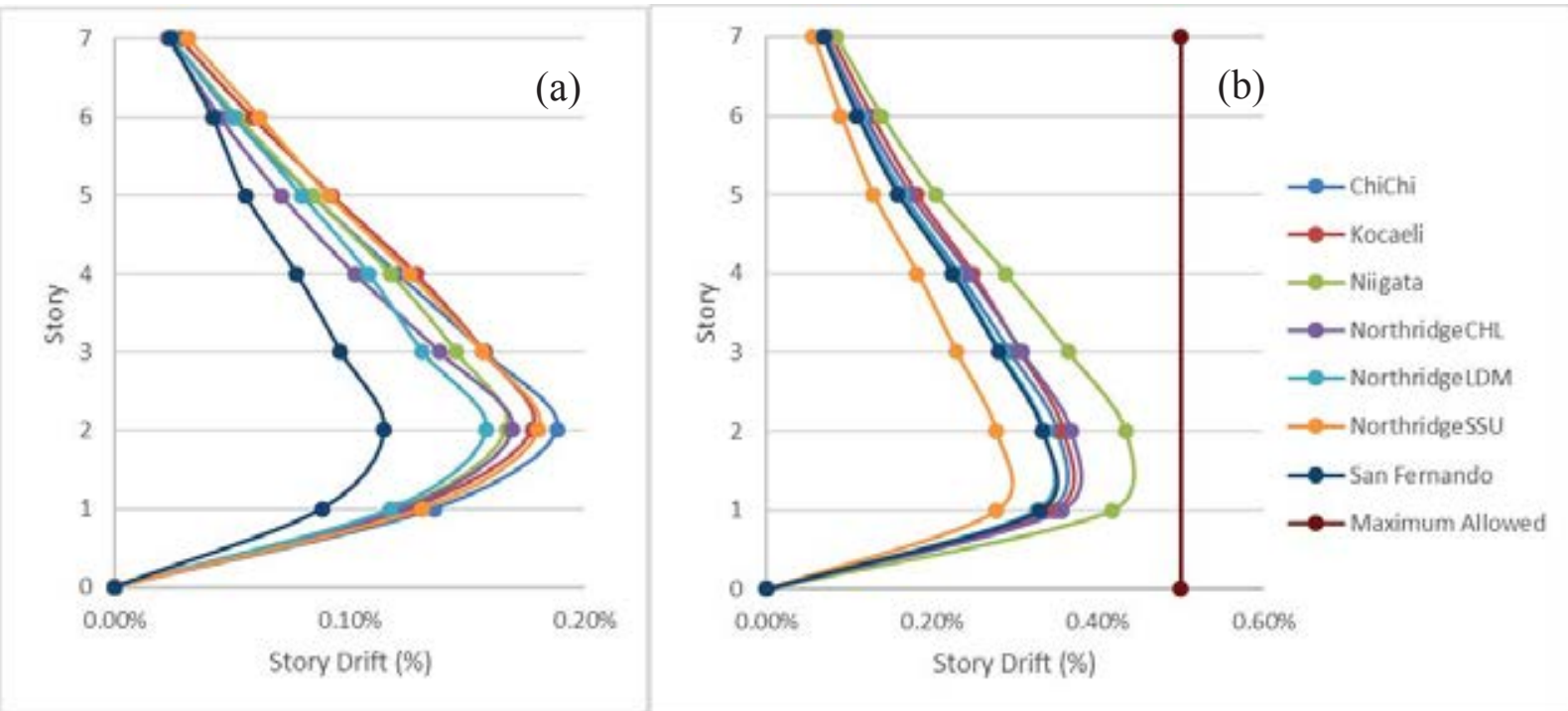

Figure 8: Maximum drift ratio for (a) fixed base model incorporating viscous dampers and (b) flexible base model incorporating viscous dampers.

The inter-story drift has an average increment of $117 \%$ for the flexible base than the fixed base case. But for both cases with viscous dampers, the maximum drift is below the limit for a moderate damage level (0.5 percent), according to Hazus [35].

The distribution of the story shear forces for both cases with viscous dampers are shown in Figure 9.
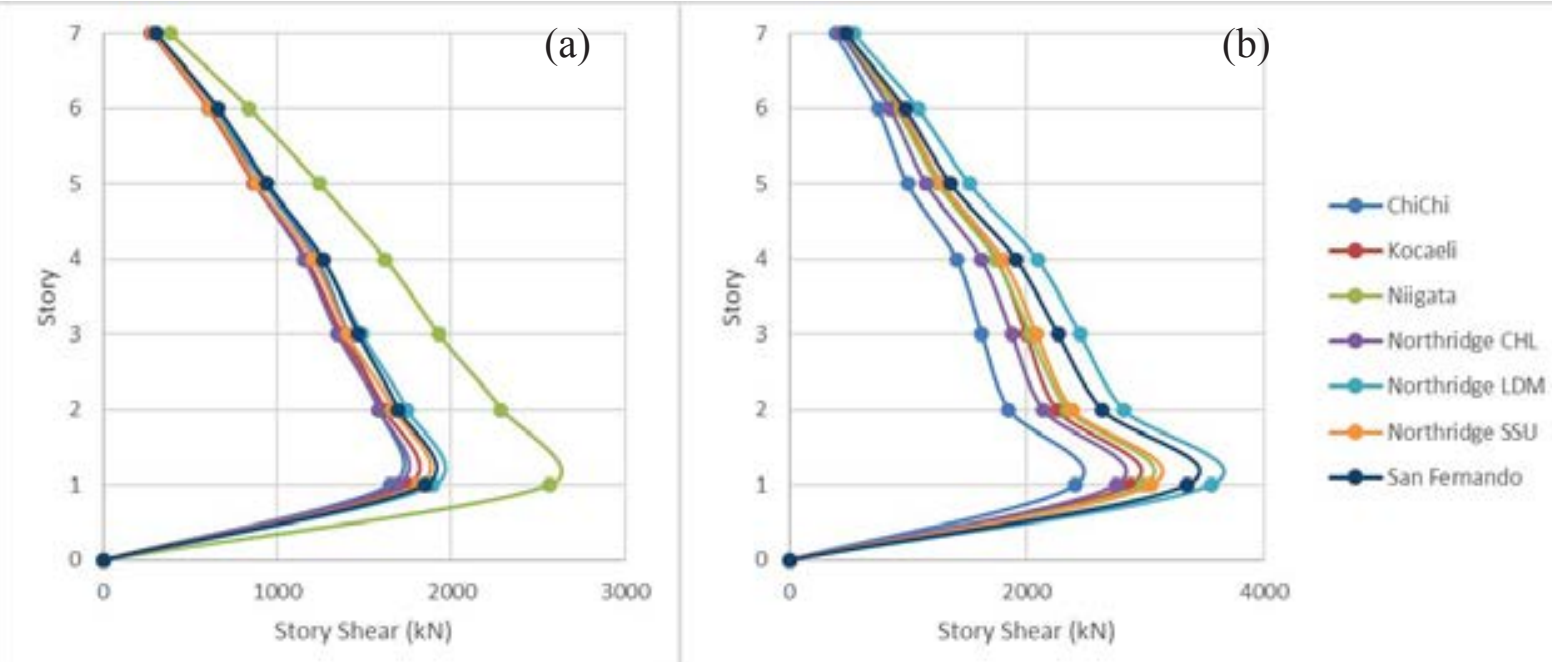

Figure 9: Shear distribution for (a) fixed base model incorporating viscous dampers and (b) flexible base model incorporating viscous dampers.

The maximum shear force increases on average $61 \%$ for the flexible base case with respect to the fixed base case.

The obtained results for the viscous dampers show stable hysteretic cycles. For space reasons, two hysteretic curves of the second-story viscous damper were presented for the Kocaeli earthquake for fixed-base and the flexible base cases (Figure 10). 

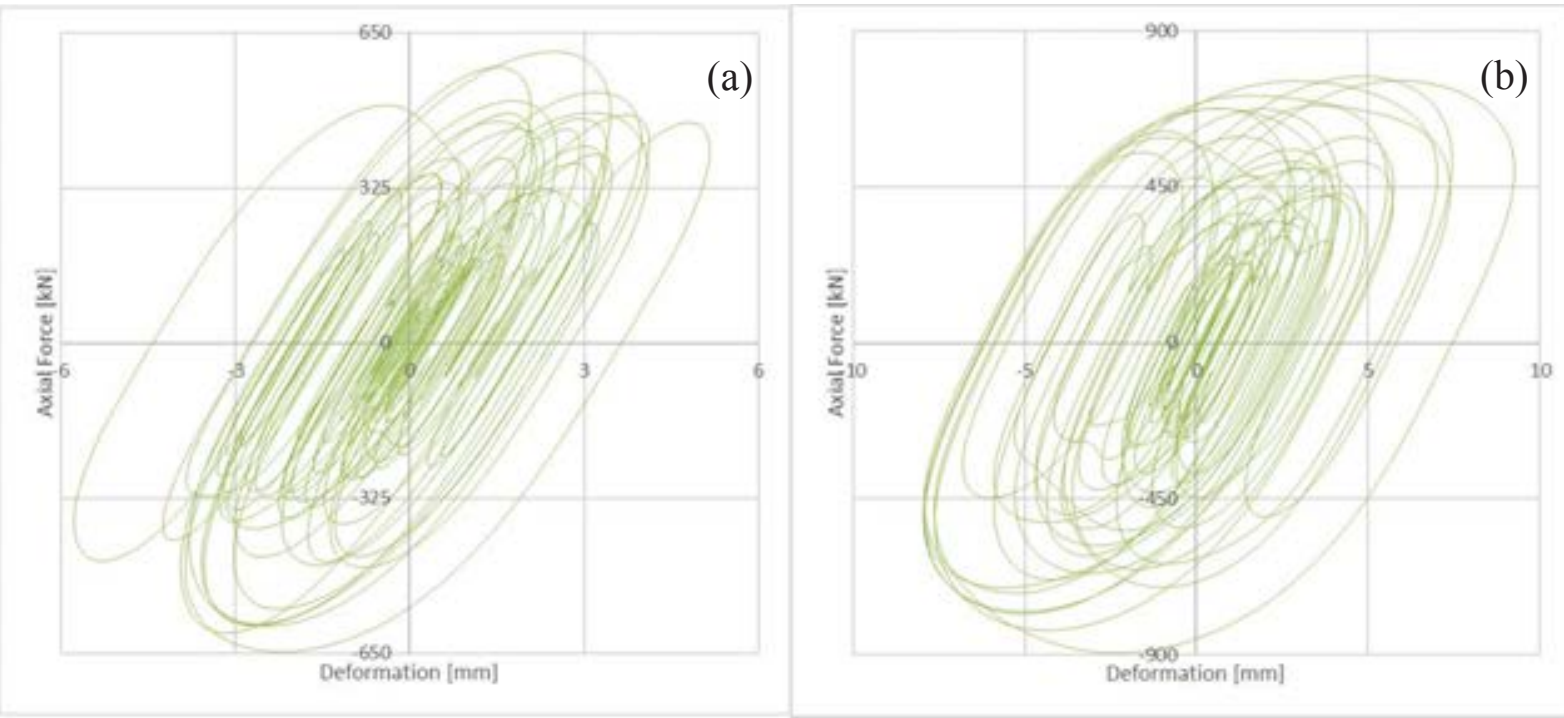

Figure 10: Hysteretic curve for K13 for Kocaeli earthquake of (a) fixed base model and (b) flexible base case.

The figures show that the dampers were successfully dissipating energy and reducing displacements of the structure. The maximum forces and deformations increased for the flexible base model, meaning that the viscous dampers have a wider working range when the soil effects are considered.

\section{CONCLUSIONS}

The SSI effects for concrete frame structures implementing viscous dampers have been investigated. The following conclusions were determined for the 7-story frame building used as case-study:

- In a comparison between the models with fixed and flexible base,the average inter-story drift increased by approximately 115 percent when the SSI is considered. Similarly, the maximum story shear force increased on average by approximately 60 percent for the model with flexible base.

- The results of the study show that the cceleration and displacement responses have inversely proportional effects when SSI is considered. Although the maximum displacement increased on average by approximately 120 percent, the acceleration response shows a slight noticeable reduction of less than 20 percent.

- For both cases implementing viscous dampers, the devices had a stable behavior and a good performance dissipating the energy. The use of viscous dampers enables the dynamic control during a seismic event, which may result in a reduction in the amount and the level of damage that both structural and non-structural elements can sustain. This is the result of the additional capacity to dissipate the energy provided by the control systems.

- There is a noticeable difference of the results when the SSI effects are considered in the analysis. For the case-study, the displacement and distribution of shear forces increases for the selected characteristics of the soil supporting the structure. Therefore, it is of high importance to consider the SSI effects when performing any type of global analysis of structures, and even more significant when the structure is categorized of high importance for a community. 


\section{REFERENCES}

[1] D. Gómez, J. Marulanda, and P. Thomson, "Control systems for dynamic loading protection of civil structures," DYNA, vol. 75, no. 155, pp. 77-89, 2008.

[2] C. Genatios and M. Lafuente, Introducción al uso de aisladores y disipadores en estructuras. 2016.

[3] O. Cundumí Sánchez, "Nonlinear Analysis of Structures Controlled With A New Variable Damping Device," in 14th World Conference on Earthquakes Engineering 14WCEE 2008, 2008.

[4] O. Cundumí Sánchez and L. E. Suárez, "A New Variable Damping Semi-Active Device Seismic Response Reduction of Civil Structure," J. Mech. Mater. Struct., vol. 2, no. 8, 2007.

[5] O. Cundumí Sánchez and S. Laboy, "Nonlinear Analysis of Structures Controlled with Passive Damper," in 17th Congreso de Ingeniería Sísmica, 2009.

[6] O. Cundumí Sánchez and S. Laboy, "Fragility Curves for Concrete Frame Buildings with Passive Controllers," in 9th US National and 10th Canadian Conference on Earthquake Engineering: Reaching Beyond Borders, 2010.

[7] F. J. P. Ocampo, "Diseño e implementación de un amortiguador de masa sintonizada (TMD) robusto para disminuir la respuesta dinámica en una tribuna debido a la interacción humano-estructura," Universidad del Valle, 2011.

[8] S. Mahin, "Lessons from Recent Earthquakes : The Need for More Resilient Cities," pp. 31-42, 2012.

[9] S. Infanti, J. Robinson, and R. Smith, "Viscous Dampers For High-Rise Buildings," 14th World Conf. Earthq. Eng., no. October 2008, 2008.

[10] ITT ENIDINE, "Viscous Dampers and Tuned Mass Dampers Ensure Buildings Stand Tall,” Jun. 2020. https://www.itt-infrastructure.com/en-US/Applications/Buildings/.

[11] L. Menglin and W. Jingning, "Effects of soil-structure interaction on structural vibration control," no. 2, 1998, pp. 189-202.

[12] I. Chowdhury and S. P. Dasgupta, Dynamics of Structure and Foundation - A Unified Approach. 2009.

[13] E. Kausel, "Early history of soil-structure interaction," Soil Dyn. Earthq. Eng., vol. 30, no. 9, pp. 822-832, 2010, doi: 10.1016/j.soildyn.2009.11.001.

[14] A. S. Veletsos and J. W. Meek, "Dynamic behaviour of building-foundation systems," Earthquake Engineering \& Structural Dynamics, vol. 3, no. 2. pp. 121-138, 1974, doi: 10.1002/eqe.4290030203.

[15] J. Avilés and L. E. Pérez-Rocha, "Evaluation of interaction effects on the system period and the system damping due to foundation embedment and layer depth," Soil Dyn. Earthq. Eng., vol. 15, no. 1, pp. 11-27, Jan. 1996, doi: 10.1016/0267-7261(95)000356.

[16] G. Mylonakis, C. Syngros, G. Gazetas, and T. Tazoh, "The role of soil in the collapse of 18 piers of Hanshin Expressway in the Kobe earthquake," Earthq. Eng. Struct. Dyn., vol. 35, no. 5, pp. 547-575, Apr. 2006, [Online]. Available:

http://doi.wiley.com/10.1002/eqe.543. 
[17] H. R. Tabatabaiefar, B. Fatahi, and B. Samali, "Seismic behavior of building frames considering dynamic soil-structure interaction," Int. J. Geomech., vol. 13, no. 4, pp. 409-420, 2013, doi: 10.1061/(ASCE)GM.1943-5622.0000231.

[18] C. Medina, J. J. Aznárez, L. A. Padrón, and O. Maeso, "Effects of soil-structure interaction on the dynamic properties and seismic response of piled structures," Soil Dyn. Earthq. Eng., vol. 53, pp. 160-175, Oct. 2013, doi: 10.1016/j.soildyn.2013.07.004.

[19] I. E. El-arab and S. Sakla, "The effect of seismic soil-structure interaction on the dynamic characteristics of structural systems on shallow foundations," 2014, no. August 2014.

[20] F. Behnamfar and M. Banizadeh, "Effects of soil-structure interaction on distribution of seismic vulnerability in RC structures," Soil Dyn. Earthq. Eng., vol. 80, pp. 73-86, 2016, doi: 10.1016/j.soildyn.2015.10.007.

[21] I. Computers \& Structures, “ETABS User's Guide.” 2019.

[22] A. M. Cortés, "Influencia de la Interacción Dinámica Suelo-Estructura en pórticos de concreto con disipadores viscosos incorporados," Pontificia Universidad Javeriana Cali, 2021.

[23] Asociación Colombiana de Ingeniería Sísmica, Requisitos generales de diseño y construcción sismo resistente, vol. Titulo A. 2010.

[24] American Society of Civil Engineers, Asce 7-16, vol. 69, no. 1782. 2017.

[25] U. of California, "NGA West2," 2018. .

[26] Departamento Administrativo de Gestión del Medio Ambiente DAGMA and Instituto Colombiano de Geología y Minería INGEOMINAS, "Estudio de Microzonificación Símica de Santiago de Cali. Convenieo 002 de 2002," 2002.

[27] C. F. Grajales, I. F. Otálvaro, and O. Cundumi, "Efectos de horizontes de suelos blandos profundos en la respuesta dinámica del campus de la PUJ Cali," in $I X$ Congreso Nacional de Ingeniería Sísmica, 2020.

[28] J. Hancock, J. J. Bommer, and P. J. Stafford, "Numbers of scaled and matched accelerograms required for inelastic dynamic analyses," Earthq. Eng. Struct. Dyn., vol. 37, no. 14 , pp. 1585-1607, Nov. 2008, doi: 10.1002/eqe.827.

[29] L. Alatik and N. Abrahamson, "An improved method for nonstationary spectral matching,” Earthq. Spectra, vol. 26, no. 3, pp. 601-617, 2010, doi: 10.1193/1.3459159.

[30] Seismosoft, "SeismoMatch - A computer program for spectrum matching of earthquake records," vol. 0. 2020.

[31] Y.-J. Lee, T.-J. Kim, and F. Maria, "Foundation Modeling Considering the SoilStructure Interaction," J. Earthq. Eng. Soc. Korea, vol. 16, no. 3, pp. 13-22, 2012, doi: 10.5000/eesk.2012.16.3.013.

[32] Federal Emergency Management Agency, Improvement of Nonlinear Static Seismic Analysis Procedures, vol. 440, no. June. 2005.

[33] E. P. C. S. Inc, “ProShake 2.0 User's Manual.” Sammamish, Washington, 2017.

[34] Federal Emergency Management Agency FEMA 356, Prestandard and Commentary 
for the Seismic Rehabilitation of Buildings, no. November. 2000.

[35] Federal Emergency Management Agency (FEMA), “HAZUS-MH MR4 Multi-Hazard Loss Estimation Methodology - Earthquake Model: Technical Manual. Department of Homeland Security," Fed. Emerg. Manag. Agency, Washington, ..., 2003, [Online]. Available: www.fema.gov/plan/prevent/hazus.

[36] Taylor Devices Inc., Fluid Viscous Dampers General Guidelines for Engineers Including a Brief History. 2020. 